\title{
UV radiation induced stress does not affect DMSP synthesis in the marine prymnesiophyte Emiliania huxleyi
}

\author{
Marion van Rijssel*, Anita G. J. Buma \\ Department of Marine Biology, University of Groningen, Centre for Ecological and Evolutionary Studies, PO Box 14, \\ 9750 AA Haren, The Netherlands
}

\begin{abstract}
A possible coupling between UV radiation (UVR; 280 to $400 \mathrm{~nm}$ ) induced stress and the production of dimethylsulfoniopropionate (DMSP), the precursor of the climate-regulating gas dimethylsulfide (DMS), was investigated in the marine prymnesiophyte Emiliania huxleyi. To this end, axenic cultures of E. huxleyi were exposed to a range of UVR doses for 2 consecutive days. During and after these treatments, growth, photosynthetic activity, cell size, DNA damage, sugar accumulation and DMSP concentrations were followed. The vulnerability of E. huxleyi for relatively low UVR doses was demonstrated by the inhibition of growth and the simultaneous occurrence of DNA damage. Also, mean cell size increased and sugars accumulated as a result of the UVR treatments. In contrast, no effect was observed on the optimal quantum yield of Photosystem II (PSII), a measure of the efficiency of photosynthesis. With increasing UVR dose, cellular DMSP content increased. However, the intracellular DMSP concentrations remained constant at the level typical for the applied temperature and salinity conditions, due to accompanying increase in cell size. The increased cellular DMSP content did not compensate, therefore, for the decreased growth rates, resulting in an overall decrease in the total amount of DMSP produced in the cultures. The UVR effects as induced in this study are assumed to be severe as compared with natural solar conditions, especially because high in situ UVAR (315 to $400 \mathrm{~nm}$ ) may ameliorate UVBR damage by activation of photorepair. Yet the presented results imply that when (increased) UV(B)R causes growth rate reduction of E. huxleyi in situ, DMSP fluxes are likely to be reduced too.
\end{abstract}

KEY WORDS: UV radiation · Phytoplankton · Emiliania huxleyi $\cdot$ Cyclobutane pyrimidine dimers · DNA $\cdot$ Thymine dimers $\cdot$ Dimethylsulfide $\cdot$ Dimethylsulfoniopropionate $\cdot$ Salinity $\cdot F_{\mathrm{v}} / F_{\mathrm{m}}$

\section{INTRODUCTION}

Prymnesiophytes are the main producers of dimethylsulfoniopropionate (DMSP), the precursor of the volatile sulfur compound dimethylsulfide (DMS). DMS is involved in climate regulation because its emission gives rise to cloud condensation nuclei that affect cloud reflectiveness (Charlson et al. 1987). Emiliania huxleyi, a cosmopolitan member of the prymnesiophytes, is known for its massive blooms mainly in tem-

*E-mail: m.van.rijssel@biol.rug.nl perate and subpolar regions (Holligan et al. 1993) and for its high DMSP content (Keller \& Korjeff-Bellows 1996). DMSP is a compatible solute that is produced as an osmolite, especially at low temperatures (Karsten et al. 1996, Van Rijssel \& Gieskes 2002). Furthermore, it may serve as an overflow metabolite during stress conditions when cells are not capable of balanced growth (Stefels 2000). Under stress the production of stressadapted enzymes is mediated by certain proteases, which facilitate the reuse of amino acids present in enzymes that are not essential in adverse conditions. DMSP production then serves as a means to reallocate nitrogen from methionine to the synthesis of new 
amino acids. In addition, Stefels (2000) postulated that DMSP could be used as an overflow of carbon when carbohydrate production exceeds cellular carbon requirements. Additions of methionine to Tetraselmis subcordiformis and Wollastonia biflora resulted in an increased DMSP production (Gröne \& Kirst 1992, Hanson et al. 1994).

It is indisputable that solar UV radiation (UVR; 280 to $400 \mathrm{~nm}$ ) negatively affects marine microalgae, judging from the many field experiments that have demonstrated UVBR-related decreases in primary production (Smith et al. 1992, Helbling et al. 1994, Neale et al. 1994, Prezelin et al. 1994, 1998, Boucher \& Prezelin 1996, McMinn et al. 1999). Inside the cell, UVBR can affect Photosystem II (PSII) efficiency (Kroon et al. 1994, Schofield et al. 1995) or the ribulose 1,5-bisphosphate carboxylase/oxygenase (RUBISCO) pool (Lesser et al. 1996). In addition, UVBR induces DNA damage, notably cyclobutane pyrimidine dimers (CPDs) (Karentz et al. 1991, Karentz 1994, Buma et al. 1996) that may arrest the cell cycle in the DNA synthesis phase. Such damage obstructs de novo synthesis of cellular components and substances required for growth and cell maintenance by replication inhibition. This may result in unbalanced growth if the damage is not readily repaired. There are several ways in which DNA damage can be repaired, one of which is photoreactivation, known to be controlled by light in the UVAR-photosynthetically active radiation (PAR) region (330 to $450 \mathrm{~nm}$, Sancar \& Sancar 1988). CPDs have been detected in situ in marine tropical picophytoplankton (Jeffrey et al. 1996a,b, Boelen et al. 2000, 2001), in temperate phytoplankton assemblages (Buma et al. 2001a, Helbling et al. 2001), and in Antarctic ice algae and phytoplankton (Prezelin et al. 1998, Buma et al. 2001b).

On top of naturally occurring UVBR stress, enhanced UVBR as a result of springtime ozone reduction further inhibits water column productivity (Smith et al. 1992, Helbling et al. 1994). Ozone depletion extends from polar into subpolar and temperate regions including those where the prymnesiophytes Phaeocystis sp. and Emiliania huxleyi form massive blooms. E. huxleyi is rather sensitive to UVBR, as concluded from laboratory studies (Buma et al. 2000, Garde \& Cailliau 2000). DNA damage and complete growth inhibition already occurred at a daily weighted UVBR dose of $400 \mathrm{~J} \mathrm{~m}^{-2}$ (biological effective dose $[\mathrm{BED}]_{\mathrm{DNA}_{300} \mathrm{~nm}}$ ). It is therefore imaginable that increased levels of UVBR as a result of ozone depletion cause damage and unbalanced growth in E. huxleyi. If so, DMSP production could be affected as well. Hefu \& Kirst (1997) already showed that high levels of UVBR inhibited DMSP production in P. antarctica cultures. Also, Sakka et al. (1997) observed elevated DMSP levels in microcosms under reduced UVR.
Based on current knowledge it is likely that a coupling exists between ozone depletion-related increases in UVBR and DMSP production by microalgae. In the present study, the effect of UVR on DMSP synthesis in Emiliania huxleyi was studied with the aim to investigate whether E. huxleyi uses DMSP as an overflow metabolite under UVR-mediated disturbance of balanced growth. UVR stress was induced in axenic cultures of E. huxleyi, after which the effects on growth, photosynthetic activity, cell size, DNA damage, sugar accumulation and DMSP concentration were followed.

\section{MATERIALS AND METHODS}

Axenic Emiliania huxleyi strain L was cultured in cotton-plugged Erlenmeyer flasks filled with artificial seawater medium described by Veldhuis \& Admiraal (1987), except for the vitamins and concentrations of $\mathrm{NO}_{3}{ }^{-}$and $\mathrm{PO}_{4}{ }^{3-}$ (88.3 and $3.6 \mu \mathrm{M}$, respectively) that were taken from Guillard (1975). The concentration of bicarbonate was doubled to $4.5 \mathrm{mM}$ to avoid carbon limitation of this coccolithophorid. Stock cultures were regularly checked for bacterial contamination by staining with Hoechst dye 33258 (Paul 1982).

At the start of a UVR experiment (both pilot and final experiment), a stock culture (adapted to $15^{\circ} \mathrm{C}$ and $200 \mu \mathrm{mol} \mathrm{m} \mathrm{m}^{-2} \mathrm{~s}^{-1}$ PAR for $\left.3 \mathrm{wk}\right)$ was inoculated (1\% $\mathrm{v} / \mathrm{v}$ ) into $1 \mathrm{l}$ medium and incubated until a cell density of $9.10^{8} \mathrm{l}^{-1}$ was reached. Seven quartz tubes $(200 \mathrm{ml})$ were filled with 3 -fold diluted culture, closed with silicone stoppers and submerged in a glass aquarium that was placed inside a culture cabinet to ensure identical temperatures during the experiments $\left(15^{\circ} \mathrm{C}\right)$. The aquarium was continuously illuminated from below with 6 tubes providing PAR $\left(200 \mu \mathrm{mol} \mathrm{m}^{-2} \mathrm{~s}^{-1}\right)$. Above the aquarium, 2 UVR lamps (Philips TL 20W/12) were placed. Each quartz tube was covered with a UVRopaque cut-off filter sleeve (Farblos $125 \mu \mathrm{m}$, Digefra) until the beginning of the experiment to allow PAR only to the cultures. During UVR exposures this filter was replaced by a $294 \mathrm{~nm}$ cut-off filter (Ultraphan UBT $500 \mu \mathrm{m})$, to allow UVAR and UVBR and to exclude UVCR emitted by the TL 20W/12 lamps. UVR exposure times for the individual tubes were $0,0.5,1,1.5,2,4$ and $7 \mathrm{~h} \mathrm{~d}^{-1}$ on 2 consecutive days. To minimize the risk of location artifacts, the tubes were repositioned 8 times a day. Lamp spectra were measured with a spectroradiometer (MACAM SR9910 double monochromator scanning spectroradiometer, Macam Photometrics, equipped with a $4.2 \mathrm{~m}$ quartz cable connected to a $4 \pi$ collector) (Fig. 1), weighted with the DNA action spectrum of Setlow (normalized at $300 \mathrm{~nm}$, Setlow 1974) and multiplied by the exposure period to give the daily

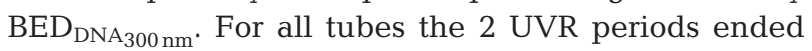




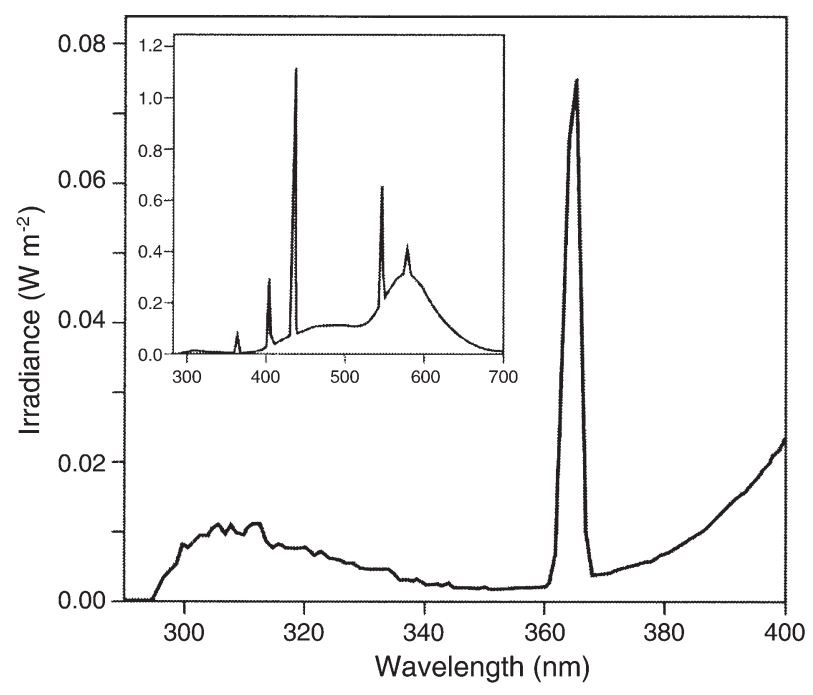

Fig. 1. Combined spectrum of the photosynthetically active radiation (PAR) and UV radiation (UVR) lamps to which the quartz tubes filled with Emiliania huxleyi culture were exposed

simultaneously (24 and $48 \mathrm{~h}$ after the beginning of the experiment). The pilot and final experiment were essentially the same except for the additional parameters measured in the final experiment (see below). After the first UVR treatment (Day 1), samples $(0.5 \mathrm{ml})$ were taken from the tubes for analysis of biomass (pilot and final experiment), after which the tubes were placed back in the water bath. After the second UVR treatment (Day 2), the tubes were harvested, during which samples were taken for biomass, as well as for analyses of DMSP (pilot and final experiment), DNA damage, PSII efficiency and sugar content (final experiment).

An electronic particle analyzer (Coulter Counter ZM equipped with Channelyser 256 and a counting tube with an $30 \mu \mathrm{M}$ inlet, Coulter Electronics) was used for analysis of cell density, average diameter and total biovolume. Particle size was calibrated with latex particles $8.7 \mu \mathrm{m}$ in diameter (Coulter Electronics). Measurement of the diameter of cells in 1 sample using a microscope revealed that the Coulter counter measurements did not include the coccolithosphere. Samples were diluted $(20 \times)$ in $0.2 \mu \mathrm{m}$ filtered medium and placed in the dark before analysis within $1 \mathrm{~h}$.

Total sugar was measured (3 samples per quartz tube) as described by Liu et al. (1973). Glucose was used as a standard.

Photosynthetic activity was assessed by measuring in vivo chlorophyll a fluorescence with a pulse-amplitude modulated fluorometer (PAM 2000, Walz). Samples were kept in the dark (to prevent photorepair) before filtering $10 \mathrm{ml}$ on a GF/F filter (1 cm diameter). Filters were mounted on the end of the fiberoptic probe and inserted into a temperature-controlled cuvette $\left(15^{\circ} \mathrm{C}\right)$ filled with seawater. The maximal quantum efficiency of 'dark-adapted' algae was determined as the ratio of variable to maximum fluorescence $\left(F_{\mathrm{v}} / F_{\mathrm{m}}\right)$ (Van de Poll et al. 2001). After application of a $5 \mathrm{~s}$ far red pulse $\left(\sim 30 \mu \mathrm{mol} \mathrm{m} \mathrm{m}^{-2} \mathrm{~s}^{-1}\right)$ used to oxidize the electron transport chain, initial fluorescence $\left(F_{0}\right)$ was measured with a red measuring light pulse $\left(\sim 0.3 \mu \mathrm{mol} \mathrm{m} \mathrm{m}^{-2} \mathrm{~s}^{-1}, 650 \mathrm{~nm}\right)$, and $F_{\mathrm{m}}$ was determined with a $800 \mathrm{~ms}$ completely saturating white light pulse $\left(\sim 9200 \mu \mathrm{mol} \mathrm{m} \mathrm{m}^{-2} \mathrm{~s}^{-1}\right)$. The samples that received the highest UVR doses were measured first. All samples were measured within $2.5 \mathrm{~h}$.

DNA damage was measured following the immunochemical method described earlier (Buma et al. 2001b), slightly modified after Boelen et al. (1999). CPD was quantified by comparing sample DNA with a dilution series of damaged standard DNA. The amount of CPDs in the standard DNA was determined by calibrating against DNA isolated from irradiated HeLa cells, with a known amount of CPDs (kindly provided by Dr. A. Vink, TNO Rijswijk, The Netherlands). The amount of CPDs in this DNA was determined by Roza et al. (1988) by means of HPLC. All measurements were done in duplicate.

For DMS and DMSP analyses, $5 \mathrm{ml}$ samples were transferred in $20 \mathrm{ml}$ crimp top vials (Chrompack) containing $50 \mu \mathrm{l}$ phosphoric acid (85\%). The acid brings the $\mathrm{pH}$ below 1, preventing conversion of DMSP to DMS. Vials were immediately sealed with a Teflonlined, butyl rubber septum (Chrompack) and stored at $4^{\circ} \mathrm{C}$ in the dark until analysis of the headspace. Vials were incubated in a $30^{\circ} \mathrm{C}$ water bath and shaken firmly before injecting a $0.5 \mathrm{ml}$ headspace sample into a Packard 437 gas chromatograph with flame ionization detector (Visscher \& van Gemerden 1991); a Supelpak $\mathrm{S}$ column was used instead of a Porapak column. This headspace value, after calibration, gives DMSconc. Then $0.5 \mathrm{ml}$ of $10 \mathrm{M} \mathrm{NaOH}$ was injected into the vial to convert all DMSP into DMS and acrylate overnight. Again, DMS was measured in the headspace (DMStotal). For calibration, DMSP (prepared according to Chambers et al. 1987) standard (0 to $10 \mu \mathrm{M})$ was converted to DMS in the same way as the samples and measured. The detection limit was $0.1 \mu \mathrm{M}$ and the duplicate measurements differed less than $5 \%$. The concentration of DMSP is usually calculated according to the formula DMSP = DMStotal - DMSconc, but DMS concentrations were never above the detection limit. Hefu \& Kirst (1997) described a UVR-related conversion of DMSP to DMS of 1 to $2 \% \mathrm{~h}^{-1}$. We did not correct for this conversion because the UVR used in their study was 15 times higher than that applied here.

For the calculations of DMSP per cell and per cell volume, we did not discriminate between particulate and dissolved DMSP. An earlier experiment with 
cultures adapted to different salinities (same amount of PAR, same temperature) revealed a linear relationship between salinity and the particulate DMSP per biovolume (DMSP concentration $[\mathrm{mM}]=13.3$ salinity [\%o] $301, \mathrm{r}^{2}=0.994, \mathrm{p}<0.0005, \mathrm{n}=5$ at $15^{\circ} \mathrm{C}$ ) and a small percentage (increasing from 3.9 to $12.7 \%$ ) of DMSP in the medium (GF/F filtration, gravity only). The expected percentage of dissolved DMSP at the salinity used in the UVR experiments is $5.6 \%$.

Statistical analysis of the data involved linear regression on the average values obtained for each of the 7 independent tubes. In case of a significant linear relationship (at $\mathrm{p}<0.05$ level) regression lines were drawn in the figures; if not, data were connected by lines.

\section{RESULTS}

Tubes received both UVBR and UVAR (Fig. 1). The UVB/UVA ratio was 0.28 , more than 10 times higher than under natural solar radiation conditions (Sakka et al. 1997). Cultures receiving biologically effective UVR doses up to $366 \mathrm{~J} \mathrm{~m}^{-2} \mathrm{~d}^{-1}$ were growing at $0.3 \mathrm{~d}^{-1}$ (data not shown). Higher UVR doses increasingly affected growth, as was observed by the difference in cell production after the 2 UVR treatments (Fig. 2C). DNA damage, however, as measured by CPD concentration, could already be observed at a dose of $244 \mathrm{~J} \mathrm{~m}^{-2} \mathrm{~d}^{-1}$ and higher (Fig. 2A). Above this threshold a linear dose-response relationship was found between the UVR dose and the induced CPDs (CPD Mega base ${ }^{-1}=$

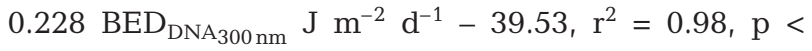
0.005). As a result of UVR exposure, the mean cell size of Emiliania huxleyi increased especially after the second UVR treatment, as is illustrated for the highest UVR dose (Fig. 3). An overall increase in mean cell size was observed with increasing UVR doses after the second UVR treatment: cell volume $\left(\mu \mathrm{m}^{3}\right)=0.0071$

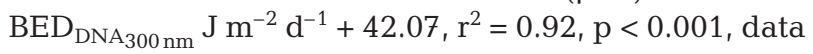
not shown).

There was no effect $\left(\mathrm{r}^{2}=0.42, \mathrm{p}=0.116\right)$ of UVR on the optimal quantum yields of PSII $\left(F_{\mathrm{v}} / F_{\mathrm{m}}=0.646 \pm\right.$
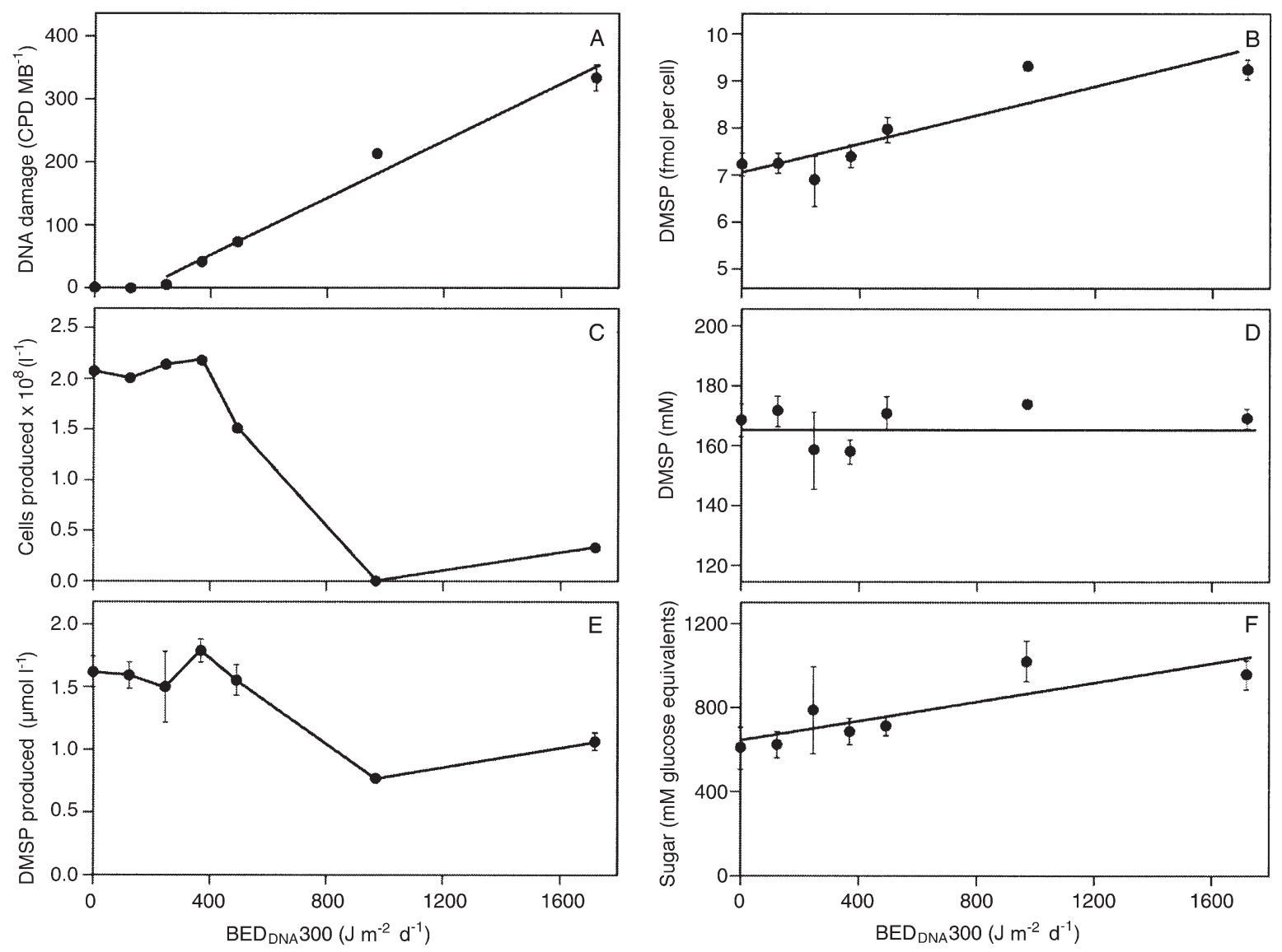

Fig. 2. Effects of UVR on Emiliania huxleyi after $2 \mathrm{~d}$ of exposure. (A) Amount of cyclobutane thymine dimers (CPDs) present in extracted DNA as a measure of DNA damage; (B) amount of dimethylsulfoniopropionate (DMSP) per cell; (C) growth, expressed as the increase in cell density; (D) concentration of DMSP in the cells (DMSP in culture divided by total biovolume); (E) DMSP $\left(\mu \mathrm{mol} \mathrm{l}^{-1}\right)$ produced in the cultures; $(\mathrm{F})$ concentration of sugars in the cells 
0.03, average $[\mathrm{AVG}] \pm$ standard error $[\mathrm{SE}]$, data not shown). Sugars accumulated in the cells when exposed to UVR. Although the cells became bigger as well, the concentration of total sugars in the cell increased with

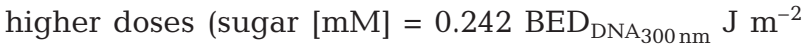
$\mathrm{d}^{-1}+636.74, \mathrm{r}^{2}=0.73, \mathrm{p}<0.0001$; Fig. 2F).

UVR exposure resulted in an increase in total DMSP per cell (DMSP [fmol cell $\left.{ }^{-1}\right]=0.00153$

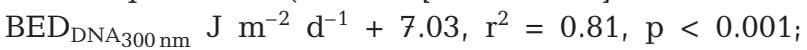
Fig. 2B). However, the amount of total DMSP per biovolume did not change $\left(r^{2}=0.10, p=0.498\right.$; Fig. 2D) and was $167.7 \pm 2.4 \mathrm{mM}(\mathrm{AVG} \pm \mathrm{SE})$ in the final experiment. This value, which includes both particulate and soluble DMSP, corresponds well with the $169 \mathrm{mM}$ expected for the salinity that was used $(34.7 \%)$, based on the relation between salinity, particulate DMSP and dissolved DMSP measured in an earlier experiment without UVR (sum of $160.5 \mathrm{mM}$ particulate DMSP and an additional $5.6 \%$ of soluble DMSP).

The pilot experiment, which comprised only the biomass and DMSP data, gave similar results: cells became bigger with increasing UVR doses (volume $\left[\mu \mathrm{m}^{3}\right]=0.013 \mathrm{BED}_{\mathrm{DNA}_{300 \mathrm{~nm}}} \mathrm{~J} \mathrm{~m}^{-2} \mathrm{~d}^{-1}+45.5, \mathrm{r}^{2}=0.77$, $p<0.01$, data not shown), and the DMSP per biovolume was $173.2 \pm 8.8 \mathrm{mM}\left(\mathrm{r}^{2}=0.002, \mathrm{p}=0.933\right.$, data not shown). The difference with the final experiment was the slightly bigger cells and a slightly higher DMSP per biovolume at the start of the experiment. Therefore, these results were not combined with those of the final experiment.

The total amount of DMSP produced in the cultures during the experiment at the 2 highest doses was less than that produced at low doses (Fig. 2E). The apparent slight increase in cell production in the tube that received the highest dose seems to be consistent with the slight increase in total DMSP in the cultures (both

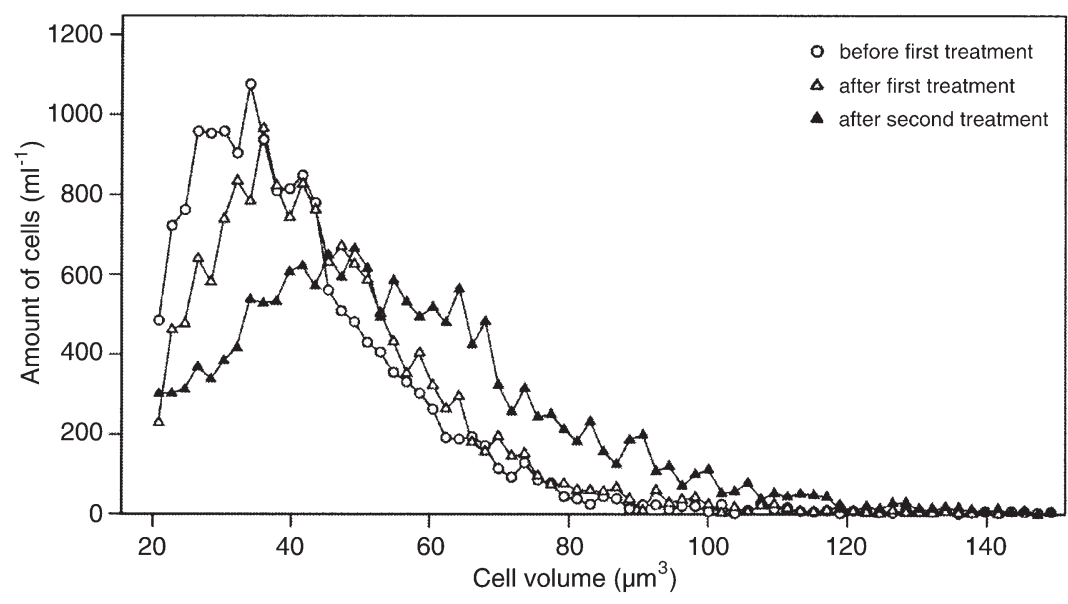

Fig. 3. Effects of UVR (daily weighted dose of $1700 \mathrm{~J} \mathrm{~m}^{-2}$ ) on the cell size distribution of Emiliania huxleyi before and after the 2 UVR treatments independent measurements). However, it should be realized that both values are the result of subtracting the starting value from the value at the end of the experiment. The difference between the actual amount of cells and DMSP in the cultures receiving 970 and $1700 \mathrm{BED}_{\mathrm{DNA}_{300 \mathrm{~nm}}}\left(\mathrm{~J} \mathrm{~m}^{-2} \mathrm{~d}^{-1}\right)$ was 10 and $13 \%$, respectively. Although significant effects were found between increasing UVR doses and some measured parameters using linear regression analysis, the combined effects (for growth and total DMSP production) do not necessarily have to be linear as well. Perhaps these respond with an abrupt change at a certain threshold and virtually the same values for cultures above that threshold.

\section{DISCUSSION}

The present study shows that UVR stress in Emiliania huxleyi does not alter the intracellular DMSP concentration. The observed UVR stress-related increase in cellular DMSP content, presumably coupled to cell size increase, could not compensate for decreased growth at doses higher than a $\mathrm{BED}_{\mathrm{DNA}_{300 \mathrm{~nm}}}$ of $488 \mathrm{~J} \mathrm{~m}^{-2}$ $\mathrm{d}^{-1}$. The total amount of DMSP produced in the cultures, therefore, decreased at high UVR doses.

The ratio of UVB to UVA applied here was such that the adverse effects of the UVR can be attributed mostly to UVBR. Clearly, low levels of biologically effective UVR caused growth rate reduction and DNA damage, whereas between 200 and 250 CPDs Mega base ${ }^{-1}$ brought about complete cell cycle arrest in Emiliania huxleyi. Obviously, repair pathways were not sufficient to prevent the accumulation of damage during UVR treatments. The weighted UVR doses used here can be considered representative for daily incident UVR doses in summer in temperate regions (Madronich 1992). However, the observed characteristics of UVR stress cannot be extrapolated to the situation in the field due to the low levels of UVAR in our experimental design. On the one hand, natural levels of UVAR addition could have favored DNA repair, thereby ameliorating the effect of UVBR on DNA (Sancar \& Sancar 1988). Indeed, the effect of UVR on CPD formation, growth rate or cell size was virtually absent in another experimental series when low levels of UVAR (approximately $4 \mathrm{~W} \mathrm{~m}^{-2}$ ) were given in addition (results not shown). On the other hand, only $40 \mathrm{CPDs}$ Mega base ${ }^{-1}$ were tolerated before cell production was affected (Fig. 2A,C), whereas between 200 to 250 CPDs Mega 
base $^{-1}$ caused complete cell cycle arrest. These CPD levels as recorded in our study fall within or are slightly above in situ ranges found in temperate or Antarctic phytoplankton assemblages (Buma et al. 2001a,b, Helbling et al. 2001). Obviously, high in situ UVAR and PAR conditions do not always guarantee an optimal balance between damage and repair. This may, for instance, lead to the accumulation of CPDs during UVR exposure hours, as found in a number of regions and phytoplankton assemblages (Jeffrey et al. 1996b, Boelen et al. 2001, Buma et al. 2001a,b, Helbling et al. 2001). In addition, this imbalance in damage and repair is likely to escalate under conditions of ozone depletion, because the selective increase in UVBR would cause increased ratios of UVBR to UVAR and UVBR to PAR.

UVR-mediated increases in cell size and DNA damage (Fig. 3) imply that the cell cycle was arrested in the $\mathrm{S}$ or G2 phase, as found in earlier studies (Buma et al. 2000, Garde \& Cailliau 2000). At the same time, no effect was observed on the optimal quantum yield of PSII, an indication of unchanged photosynthetic efficiency (Hofstraat et al. 1994), whereas sugars accumulated as a result of UVR treatment. These results indicate that, as a result of continued photosynthetic performance, the carbon that otherwise would have been incorporated into a balanced set of substances (among others, DNA) was temporarily stored in the sugar pool. Such overflow metabolism is often observed when cells are not able to produce biomass in an optimal way, for example in the case of nutrient limitation (Myklestad 1989). More than 10-fold higher UVR levels than in this experiment $(14 \times)$ did affect ${ }^{14} \mathrm{C}$ incorporation by Emiliania huxleyi in the study of Garde \& Cailliau (2000).

The stress induced by UVR did not result in altered DMSP physiology, as could be judged from the unchanged DMSP concentration in the cells. Values corresponded with earlier observations for this temperature and salinity. Apparently, DMSP synthesis was not hampered by UVR, nor was it used as a way to release superfluous carbon. This observation corresponds well with the $\mathrm{DO}^{14} \mathrm{C}$ excretion rates estimated by Garde \& Cailliau (2000) that followed $\mathrm{PO}^{14} \mathrm{C}$ with and without UVR treatment. Although we cannot exclude that the percentage of DMSP in the medium at stress conditions was higher than the $6 \%$ measured in earlier experiments, increased production appears unlikely since it would have resulted in higher values for DMSP volume $^{-1}$. The observed increase in the amount of DMSP cell ${ }^{-1}$ upon increased UVR shows how misleading this expression of DMSP content is in studies related to DMSP physiology (Keller 1991, Stefels 2000).

Despite the fact that DMSP synthesis was in balance with the increase in cell volume, the total amount of biomass formed was affected by UVR, and as a consequence the total production of DMSP in the cultures was depressed by UVR (Fig. 2E). Similarly, the inhibition of DMSP production observed in cultures of Phaeocystis antarctica under high levels of UVR (Hefu \& Kirst 1997) is most likely due to growth inhibition rather than to specific effects on DMSP metabolism.

In conclusion, this study has shown that in a worst case scenario, where UVR stress causes unbalanced growth in Emiliania huxleyi, the intracellular DMSP concentration remains unchanged. DMSP, in this case of stress, was not used as an overflow metabolite. Yet, when UVBR stress occurs in E. huxleyi in the field, DMSP production might be affected simply due to reduced production of biomass. Whether E. huxleyi experiences DNA damage under natural solar conditions or ozone depletion events should be revealed by field experiments. Only then can we estimate to what extent DMSP production is negatively affected by solar UVBR. Finally, how this affects DMS formation depends on other factors as well, such as UVR-mediated changes in bacterial composition and activity.

Acknowledgements. The authors thank Anja Eggert for the PSII efficiency measurements, Sanna Kipinä for the control experiment with UVAR, and Jacqueline Stefels for valuable discussions. M.v.R. was supported by funding from the Dutch Government, National Research Program on Global Air pollution and Climate Change No 013/1204.10, and A.G.J.B. by the Dutch Committee for Antarctic Research (Dutch Science Foundation, Project 751-499-02).

\section{LITERATURE CITED}

Boelen P, Obernosterer I, Vink AA, Buma AGJ (1999) Attenuation of biologically effective UV radiation in tropical Atlantic waters measured with a biochemical DNA dosimeter. Photochem Photobiol 69:34-40

Boelen P, de Boer MK, Kraay GW, Veldhuis MJW, Buma AGJ (2000) UVBR induced DNA damage in natural marine picoplankton assemblages in the tropical Atlantic Ocean. Mar Ecol Prog Ser 193:1-9

Boelen P, Veldhuis MJW, Buma AGJ (2001) Accumulation and repair of UVBR mediated DNA damage in marine tropical picoplankton subjected to mixed and simulated non-mixed conditions. Aquat Microb Ecol 24:265-274

Boucher NP, Prezelin BB (1996) Spectral modeling of UV inhibition of in situ Antarctic primary production using a field derived biological weighting function. Photochem Photobiol 64:407-418

Buma AGJ, van Hannen EJ, Veldhuis MJW, Gieskes WWC (1996) UV-B induces DNA damage and DNA synthesis delay in the marine diatom Cyclotella sp. Proc 2nd Algal Photobiol Workshop, Malaga, October 1994. Sci Mar 60(Suppl 1):101-105

Buma AGJ, van Oyen T, van de Poll W, Veldhuis MJW, Gieskes WWC (2000) On the high sensitivity of the marine prymnesiophyte Emiliania huxleyi to ultraviolet-B radiation. J Phycol 36:296-303

Buma AGJ, Helbling EW, de Boer MK, Villafane VE (2001a) 
Patterns of DNA damage and photoinhibition in temperate South-Atlantic picophytoplankton exposed to solar ultraviolet radiation. Eur J Photochem Photobiol 62:9-18

Buma AGJ, de Boer MK, Boelen P (2001b) Depth distributions of DNA damage in Antarctic marine phyto- and bacterioplankton exposed to summertime ultraviolet radiation. J Phycol 37:200-208

Chambers ST, Kunin CM, Miller D, Hamada A (1987) Dimethylthetin can substitute for glycine betaine as an osmoprotectant molecule for Escherichia coli. J Bacteriol 169:4845-4847

Charlson RJ, Lovelock JE, Andreae MO, Warren SG (1987) Oceanic phytoplankton, atmospheric sulphur, cloud albedo and climate. Nature 326:655-661

Garde K, Cailliau C (2000) The impact of UV-B radiation and different PAR intensities on growth, uptake of ${ }^{14} \mathrm{C}$, excretion of DOC, cell volume, and pigmentation in the marine prymnesiophyte, Emiliania huxleyi. J Exp Mar Biol 247: 99-112

Gröne T, Kirst GO (1992) The effect of nitrogen deficiency, methionine and inhibitors of methionine metabolism on the DMSP contents of Tetraselmis subcordiformis (Stein). Mar Biol 112:497-503

Guillard RRL (1975) Culture of phytoplankton for feeding marine invertebrates. In: Smith WL, Changley MH (eds) Culture of marine invertebrate animals. Plenum Publishers, New York, p 29-60

Hanson AD, Rivoal J, Paquet L, Gage DA (1994) Biosynthesis of 3-dimethylsulfoniopropionate in Wollastonia biflora (L.) DC. Plant Physiol 105:103-110

Hefu Y, Kirst GO (1997) Effect of UV-radiation on DMSP content and DMS formation of Phaeocystis antarctica. Polar Biol 18:402-409

Helbling EW, Villafane VE, Holm-Hansen O (1994) Effects of ultraviolet radiation on Antarctic marine photosynthesis with particular attention to the influence of mixing. In: Weiler CS, Penhale, PA (eds) Ultraviolet radiation in Antarctica: measurements and biological effects. Antarctic Research Series, Vol 62. American Geophysical Union, Washington, DC, p 207-229

Helbling EW, Buma AGJ, de Boer MK, Villafañe VE (2001) In situ impact of solar ultraviolet radiation on photosynthesis and DNA in temperate marine phytoplankton. Mar Ecol Prog Ser 211:43-49

Hofstraat JW, Peeters JCH, Snel JFH, Geel C (1994) Simple determination of photosynthetic efficiency and photoinhibition of Dunaliella tertiolecta by saturating pulse fluorescence measurements. Mar Ecol Prog Ser 103:187-196

Holligan PM, Fernandez E, Aiken J, Balch WM and 11 others (1993) A biogeochemical study of the coccolithophore, Emiliania huxleyi, in the North Atlantic. Global Biogeochem Cycles 7:879-900

Jeffrey WH, Aas P, Lyons MM, Coffin RB, Pledger RJ, Mitchell DL (1996a) Ambient solar radiation-induced photodamage in marine bacterioplankton. Photochem Photobiol 64:419-427

Jeffrey WH, Pledger RJ, Aas P, Hager S, Coffin RB, Von Haven R, Mitchell DL (1996b) Diel and depth profiles of DNA photodamage in bacterioplankton exposed to ambient solar ultraviolet radiation. Mar Ecol Prog Ser 137: 283-291

Karentz D (1994) Ultraviolet tolerance mechanisms in Antarctic marine organisms. In: Weiler CS, Penhale PA (eds) Ultraviolet radiation in Antarctica: measurements and biological effects. Antarctic Research Series, Vol 62. American Geophysical Union, Washington, DC, p 93-110

Karentz D, Cleaver JE, Mitchell DL (1991) Cell survival char- acteristics and molecular responses of Antarctic phytoplankton to ultraviolet-B radiation. J Phycol 27:326-341

Karsten U, Kück K, Vogt C, Kirst GO (1996) Dimethylsulfoniopropionate production in phototrophic organisms and its physiological function as a cryoprotectant. In: Kiene RP, Visscher PT, Keller MD, Kirst GO (eds) Biological and environmental chemistry of DMSP and related sulfonium compounds. Plenum Press, New York, p 143-153

Keller MD (1991) Dimethyl sulfide production and marine phytoplankton: the importance of species composition and cell size. Biol Oceanogr 6:375-382

Keller MD, Korjeff-Bellows W (1996) Physiological aspects of the production of dimethylsulfoniopropionate (DMSP) by marine phytoplankton. In: Kiene RP, Visscher PT, Keller MD, Kirst GO (eds) Biological and environmental chemistry of DMSP and related sulfonium compounds. Plenum Press, New York, p 131-142

Kroon BMA, Schofield O, Prezelin BB (1994) Icecolors '93: UV-B radiation specifically decreases photosystem II (PsII) quantum yield in a field community of Antarctic ice algae exposed to natural daylight. EOS 75:200

Lesser MP, Neale PJ, Cullen JJ (1996) Acclimation of Antarctic phytoplankton to ultraviolet radiation: ultravioletabsorbing compounds and carbon fixation. Mol Mar Biol Biotechnol 5:314-325

Liu D, Wong PTS, Dutha BJ (1973) Determination of carbohydrate in lake sediment by a modified phenol-sulfuric acid method. Water Res 7:741-746

Madronich S (1992) Implications of recent total atmospheric ozone measurements for biologically active ultraviolet radiation reaching the earth's surface. Geophys Res Lett 19:37-40

McMinn A, Ashworth C, Ryan K (1999) Growth and productivity of Antarctic sea ice algae under PAR and UV irradiances. Bot Mar 42:401-407

Myklestad SM (1989) Production, chemical structure, metabolism, and the function of the $(1 \rightarrow 3)$-linked, $\beta$-D-glucans in diatoms. Biol Oceanogr 6:313-326

Neale PJ, Lesser MP, Cullen JJ (1994) Effects of ultraviolet radiation on the photosynthesis of phytoplankton in the vicinity of McMurdo Station, Antarctica. In: Weiler CS, Penhale PA (eds) Ultraviolet radiation in Antarctica: measurements and biological effects. Antarctic Research Series, Vol 62. American Geophysical Union, Washington, DC, p 125-142

Paul JH (1982) Use of Hoechst dyes 33258 and 33342 for enumeration of attached and planktonic bacteria. Appl Environ Microbiol 43:939-944

Prezelin BB, Boucher NP, Smith RC (1994) Marine primary production under the influence of the Antarctic ozone hole: Icecolors '90. In: Weiler CS, Penhale PA (eds) Ultraviolet radiation in Antarctica: measurements and biological effects. Antarctic Reserach Series, Vol 62. American Geophysical Union, Washington, DC, p 159-186

Prezelin BB, Moline MA, Matlick HA (1998) Icecolors '93: spectral UV radiation effects on Antarctic frazil ice algae. Antarct Res Ser 73:45-83

Roza L, van der Wulp KJM, McFarlane SJ, Lohman PHM, Baan RA (1988) Detection of cyclobutane thymine dimers in DNA of human cells with monoclonal antibodies raised against thymine dimer-containing tetranucleotide. Photochem Photobiol 48:627-633

Sakka A, Gosselin M, Levasseur M, Michaud S, Monfort P, Demers S (1997) Effects of reduced ultraviolet radiation on aqueous concentrations of dimethylsulfoniopropionate and dimethylsulfide during a microcosm study in the Lower St. Lawrence Estuary. Mar Ecol Prog Ser 149:227-238 
Sancar A, Sancar GB (1988) DNA repair enzymes. Annu Rev Biochem 57:29-67

Schofield O, Kroon BMA, Prezelin BB (1995) Impact of ultraviolet-B radiation on photosystem II activity and its relationship to the inhibition of carbon fixation rates for Antarctic ice algae communities. J Phycol 31:703-715

Setlow RB (1974) The wavelengths in sunlight effective in producing skin cancer: a theoretical analysis. Proc Natl Acad Sci USA 71:3363-3366

Smith RC, Prezelin BB, Baker KS, Bidigare RR and 9 others (1992) Ozone depletion: ultraviolet radiation and phytoplankton biology in Antarctic waters. Science 255: 952-959

Stefels J (2000) Physiological aspects of the production and conversion of DMSP in marine algae and higher plants.

Editorial responsibility: Fereidoun Rassoulzadegan, Villefranche-sur-Mer, France
J Sea Res 43:183-197

Van de Poll WH, Eggert A, Buma AGJ, Breeman M (2001) Effects of UV-B-induced DNA damage and photoinhibition on growth of temperate marine red macrophytes: habitat-related differences in UV-B tolerance. J Phycol 37: 30-37

Van Rijssel M, Gieskes WWC (2002) Temperature, light, and the dimethylsufoniopropionate (DMSP) content of Emiliania huxleyi (Prymnesiophyceae). J Sea Res 48 (in press)

Veldhuis MJW, Admiraal W (1987) Influence of phosphate depletion on the growth and colony formation of Phaeocystis pouchetii. Mar Biol 95:47-54

Visscher PT, Van Gemerden H (1991) Photo-autotrophic growth of Thiocapsa roseopersicina on dimethyl sulfide. FEMS Microbiol Lett 81:247-50

Submitted: September 4, 2001; Accepted: March 6, 2002 Proofs received from author(s): May 15, 2002 